Lawrence A. Cremin Merle L. Borrowman

Lloyd P. Jorgensen Archibald W. Anderson Franklin Parker Raymond E. Callahan J.J. Chambliss Robert L. McCaul Ann Keppel Paul Nash David B. Tyack Henry J. Perkinson Charles Burgess Patricia Albjerg Graham John H. Calam Vincent P. Lannie Michael B. Katz

Geraldine Joncich Clifford Clarence Karier Jurgen Herbst Wayne J. Urban Carl F. Kaestle Sol Cohen Marvin Lazerson Douglas Sloan

\section{PAST PRESIDENTS}

Teachers College, Columbia University

1959-60 University of Wisconsin (now the Univ. 1960-61 of California, Berkeley)

University of Missouri

1961-62

University of Illinois (deceased)

1962-63

University of Texas

1963-64

1964-65

1965-66

Rutgers University

1966-67

1967-68

1969-69

1969-70

1970-71

1971-72

1972-73

1973-74

1974-75

1975-76

University of Toronto (now Univ.

of Pennsylvania)

University of California, Berkeley 1977

University of Illinois

1978

University of Wisconsin $\quad 1979$

Georgia State University 1980

University of Wisconsin 1981

University of California, Los Angeles 1982

University of British Columbia 1983

Columbia University, Teachers College 1984 


\section{CONTENTS}

\section{ARTICLES}

Not Only Ours But Others: The Quaker Teaching Daughters of the MidAtlantic, 1790-1850

by Joan $M$. Jensen

Vocationalism for Home and Work: Women's Education in the United States, $1880-1930$

by John L. Rury

"The Ladies Want to Bring about Reform in the Public Schools": Publi Education and Women's Rights in the Post-Civil War South.

by Kathleen C. Berke

From Widowhood to Wickedness: The Politics of Class and Gender in N York City Private Charity, 1799-1860

$$
\text { by Amy Gilmo }
$$

Teachers, Gender, and Bureaucratizing School Systems in Nineteen Century Montreal and Toronto

$$
\text { By Marta Danylewycz and Alison Prentic }
$$

The WCTU and Educational Strategies on the Canadian Prairie

by Nancy $M$. Sheehat

\section{ESSAY-REVIEWS}

Educating Edwardians

by Annette K. Baxter

Progressive Women

by Joyce Antler

Educating Women in Pre-Modern Europe

Collegiate Women in Canada

$$
\text { by Nancy } M \text {. Sheehan }
$$

Northern Philanthropy and Black Education

\section{EDITOR'S NOTE}

Our cover depicts the West Town Boarding School in Chester County, Peninsylvania. It is reprinted courtesy of the Friends Historical Library, Swarthmore College, Swarthmore, Pennsylvania. 